\title{
Pengaruh Kompensasi Terhadap Kinerja Karyawan Pada PT Mora Telematika Indonesia Jakarta
}

\author{
Mia Hardina ${ }^{\mathrm{a}, 1, *}$, Resista Vikaliana ${ }^{\mathrm{b}, 2}$ \\ a Program Studi Administrasi Bisnis, Fakultas Ilmu Administrasi, Institut Ilmu Sosial dan Manajemen Stiami

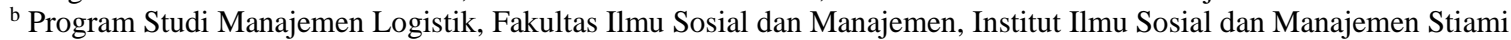 \\ ${ }^{2}$ resista@stiami.ac.id / dosenresistaok@gmail.com* \\ * corresponding author
}

\section{ARTICLE INFO}

\section{Article History}

Received

Revised

Accepted

Keywords

Compensation;

Employee Performance;

Regression

\begin{abstract}
This research was conducted because the performance of employees at PT Mora Telematics Indonesia is not optimal so it is suspected that there is an effect of compensation on employee performance at PT Mora Telematics Indonesia Jakarta. This research uses a quantitative approach with correlational research. The study population was 150 employees with a sample of 60 respondents who were taken using simple random sampling technique and data collection techniques using a questionnaire. Simple Linear Regression and Hypothesis Testing were used in this study. Based on the results of the analysis, it is known that there is a positive and significant influence between compensation and performance. Thus $\mathrm{H} 1$ is accepted and $\mathrm{HO}$ is rejected. The effect of compensation on performance is indicated by the regression equation $\mathrm{Y}=$. The results also show a correlation coefficient or $r$ of 0.452 , which means that there is a moderate relationship between the independent variable, namely compensation to the dependent variable, namely employee performance. Meanwhile, the coefficient of determination or r-square of 0.204 shows that compensation for performance has an effect of $20.4 \%$ and the remaining $79.6 \%$ is influenced by other variables not observed in this study.
\end{abstract}

\section{PENDAHULUAN}

Dalam organisasi seperti perusahaan, senantiasa diupayakan meningkatkan kinerja karyawannya. Usaha ini dilakukan dengan harapan tujuan perusahaan dapat tercapai. Pekerjaan karyawan yang berhubungan kuat denga tujuan strategis, lalu kepuasan pada konsumer serta berkontribusi secara ekonomi merupakan pengertian kinerja.(Armstrong \& Baron, 2005)

Untuk meningkatkan kinerja karyawan yang baik, bukanlah hal yang mudah. Banyak faktor yang mempengaruhinya, misal kompensasi. Bila hal ini difahami oleh perusahaan, maka karyawan akan lebih termotivasi dalam bekerja dan bertanggung jawab terhadap pekerjaannya. Bagi seorang karyawan, memperoleh kompensasi adalah salah satu tujuan dalam bekerja. Kompensasi adalah hubungan resiprokal antara perusahaan dengan karyawan dan merupakan balas jasa dari perusahaan atas kerja dari karyawan. Dalam mempertahankan Sumber Daya Manusia/ SDM, perusahaan perlu mengupayakan program kompensasi (Handoko, 2014). Penelitian sebelumnya terkait kompensasi terhadap kinerja menunjukkan pengaruh signifikan dan positif (Leonardo \& Andreani, 2015; Nurcahyani \& Adnyani, 2016; Poluakan et al., 2019; Shalahuddin \& Marpaung, 2014).

Seperti halnya PT.Mora Telematika Indonesia Jakarta sebuah perusahaan yang bergerak dibidang pelayanan jaringan Telematika. Keberadaannya merupakan bagian penting dari pelayanan publik untuk memberikan kemudahaan mendapatkan jaringan kepada masyakarat. Perusahaan ini memiliki visi dan misi yang sangat kuat yaitu menyediakan kuliatas jaringan dan nilai terbaik untuk layanan infrastruktur telematika inovatif dan menjadi mitra bisnis yang handal yang tumbuh dengan semua pemangku kepentingan. Dengan visi misi yang dimiliki PT.Mora Telematika Indonesia Jakarta, maka dinilai amat penting untuk meningkatkan produktivitas kinerja setiap karyawannya dalam mencapai tujuan perusahaan. Pengelolaan untuk mencapai kinerja secara keseluruhan dalam melayani masyarakat dibidang jaringan Telematika. Salah satu jasa pelayanan yang diberikan oleh PT. Mora Telematika Indonesia adalah Oxygen.id. Oxygen.id ini mulai peroperasi pada tahun 2018, layanan yang diberikan berupa layanan internet dan IPTV retail. Namun 
tidak semua karyawan yang bekerja di PT Mora Telematika memiliki kinerja yang baik, hal tersebut dapat dibuktikan dengan laporan kinerja karyawan sebagai berikut

Tabel 1 Data Report Target Kinerja yang Harus Dicapai pada Bagian Teknikal Dalam Menangani Produk Oygen.Id

\begin{tabular}{|c|l|c|c|c|}
\hline No & \multicolumn{1}{|c|}{ Indikator Kinerja } & $\begin{array}{c}\text { Target } \\
\text { Pencapaian \& } \\
\text { Penyelesaian }\end{array}$ & Realisasi & $\begin{array}{c}\text { Achive / Non } \\
\text { Achive }\end{array}$ \\
\hline 1 & Laporan SLA Internet & $99.50 \%$ & $95.99 \%$ & Non Achive \\
\hline 2 & Laporan SLA IPTV & $99.50 \%$ & $98.69 \%$ & Non Achive \\
\hline 3 & Ticket performance visit & Maks 72 Jam & 74 Jam 25 menit & Non Achive \\
\hline 4 & $\begin{array}{l}\text { Ticket performance non } \\
\text { visit }\end{array}$ & Maks 8 Jam & 5 Jam 15 menit & Achive \\
\hline 5 & WO performance instalasi & Maks 3 Hari & 2 hari 7 detik & Achive \\
\hline 6 & $\begin{array}{l}\text { WO performance } \\
\text { maintenance }\end{array}$ & Maks 3 Hari & 1 hari 32 Menit & Achive \\
\hline 7 & Customer growth & $7.40 \%$ & $5.2 \%$ & Non Achive \\
\hline 8 & Customer with TV & $50 \%$ & $48.4 \%$ & Non Achive \\
\hline \hline
\end{tabular}

Sumber: Report Retail, 2018

Pada Tabel 1 terlihat bahwa kinerja PT Mora Telematika Indonesia dalam penanganan produk Oxygen.ID target masih banyak indikator kinerja yang belum sesuai dengan target yang ditentukan perusahaan seperti indikator kinerja nomor 1,2,3,7,dan 8 hanya nomor 4,5,6 yang sudah mencapai atau melewati target yang harus dicapai dari perusahaan.

Berdasarkan fenomena di atas, diduga bahwa kompensasi yang diberikan perusahaan kurang sesuai, hal itu dapat dibuktikan oleh isu yang tersebar di kalangan karyawan saat ini bahwa kompensasi yang mereka terima kurang sesuai dengan pekerjaan dan tanggung jawab mereka terhadap perusahaan. Ditambah lagi mengenai upah lembur yang terkadang pencairannya sering terlambat., sehingga akhirnya berdampak terhadap kinerja pegawai yang menjadi tidak efektif. Sehingga penelitian ini bertujuan mengetahui apakah kompensasi berpengaruh terhadap kinerja karyawan di PT Mora Telematika Indonesia dan mengetahui seberapa besar pengaruh kompensasi terhadap kinerja karyawan di PT Mora Telematika Indonesia.

\section{METODE PENELITIAN}

Pendekatan kuantitatif digunakan dalam penelitain ini. Uji regresi linier sederhana dan uji hipotesis $\mathrm{t}$ diterapkan untuk menguji pengaruh yang signifikan antara variabel independen terhadap variabel dependen. Kerangka teori dalam penelitian ini terlihat pada Gambar 1.

\begin{tabular}{|c|c|c|}
\hline $\begin{array}{l}\text { Kompensasi }(X) \\
\text { Dimensi: } \\
\text { 1. Kompensasi } \\
\text { langsung } \\
\text { 2. Kompensasi } \\
\text { tidak langsung }\end{array}$ & H1 & $\begin{array}{l}\text { Kinerja (Y) } \\
\text { Dimensi: } \\
\text { 1. Kuantitas } \\
\text { kerja } \\
\text { 2. Kualitas kerja }\end{array}$ \\
\hline $\begin{array}{l}\text { Nawawi } \\
(2011: 316)\end{array}$ & & $\begin{array}{l}\text { 4. Tanggung } \\
\text { jawab } \\
\text { 5. Inisiatif } \\
\text { Mangkunegara } \\
\text { (2011:61) }\end{array}$ \\
\hline
\end{tabular}

Gambar 1. Kerangka Teori Penelitian

Sumber: Nawawi (2011), Mangkunegara (2011) 
Pada Gambar 1 terlihat bahwa variabel independen pada penelitian ini adalah Kompensasi. Sedangkan variabel dependen pada penelitian ini adalah Kinerja Karyawan. Analisis data pada penelitian ini dibantu pengolahannya dengan software SPPS (Vikaliana \& Irwansyah, 2019).

Variabel Kompensasi menggunakan indikator-indikator kuesioner merujuk bentuk-bentuk kompensasi. Bentuk-bentuk kompensasi sendiri terbagi 2 yaitu kompensasi langsung dan kompensasi tidak langsung(Nawawi, 2011).

Variabel dependen adalah Kinerja Karyawan. Hasil pekerjaan dari karyawan baik kualitas maupun kuantitas yang membantu organisasi dalam mencapai tujuannya disebut dengan kinerja karyawan (Mangkunegara, 2007). Variabel Kinerja Karyawan ini terdiri atas lima dimensi, yakni kualitas, kuantitas, kerjasama, tanggung jawab, serta inisiatif (Mangkunegara, 2007).

Kisi - kisi variabel pada penelitian ini diuraikan dalam Tabel 2 berikut

Tabel 2 Kisi-kisi Variabel

\begin{tabular}{|c|c|c|c|}
\hline Variabel dan konsep & Dimensi & Indikator & Item \\
\hline \multirow{4}{*}{$\begin{array}{c}\text { Kompensasi } \\
\text { (dependent variabel) }\end{array}$} & \multirow{3}{*}{ Kompensasi langsung } & Gaji & 1,2 \\
\hline & & Bonus & 3 \\
\hline & & Tunjangan jabatan & 4 \\
\hline & \multirow{3}{*}{$\begin{array}{l}\text { Kompensasi tidak } \\
\text { langsung }\end{array}$} & Tunjangan kesehatan & 5,6 \\
\hline \multirow[t]{2}{*}{ (Nawawi, 2011) } & & Tunjangan Hari Raya & 7 \\
\hline & & Tunjangan program pensiun & 8 \\
\hline \multirow{10}{*}{$\begin{array}{l}\text { Kinerja (Variabel } \\
\text { Independent) }\end{array}$} & \multirow[b]{2}{*}{ Kuantitas kerja } & $\begin{array}{l}\text { Kecepatan dalam menyelesaikan } \\
\text { pekerjaan }\end{array}$ & 17 \\
\hline & & $\begin{array}{l}\text { Kemampuan dapat menyelesaikan } \\
\text { pekerjaan sesuai target yang } \\
\text { ditentukan }\end{array}$ & 18 \\
\hline & \multirow{3}{*}{ Kualitas kerja } & $\begin{array}{l}\text { Kerapihan dalam menyeleasaikan } \\
\text { pekerjaan }\end{array}$ & 19 \\
\hline & & $\begin{array}{l}\text { Ketelitian dalam menyelesaikan } \\
\text { pekerjaan }\end{array}$ & 20 \\
\hline & & $\begin{array}{l}\text { Hasil kerja sesuai yang } \\
\text { diharapkan perusahaan }\end{array}$ & 21 \\
\hline & \multirow{2}{*}{ Kerjasama } & $\begin{array}{l}\text { Dapat bekerjasama baik dengan } \\
\text { satu kelompok }\end{array}$ & 22 \\
\hline & & $\begin{array}{l}\text { Dapat mengikuti arahan yang } \\
\text { diberikan oleh kelompok }\end{array}$ & 23 \\
\hline & \multirow{2}{*}{ Tanggung jawab } & $\begin{array}{l}\text { Hasil kerja dapat dipertanggung } \\
\text { jawabkan }\end{array}$ & 24 \\
\hline & & $\begin{array}{l}\text { Keputusan yang dibuat dapat } \\
\text { dipertanggung jawabkan }\end{array}$ & 25 \\
\hline & Inisiatif & $\begin{array}{l}\text { Dapat menggunakan kemapuan } \\
\text { dan keterampilan dalam } \\
\text { menyelesaikan pekerjaan }\end{array}$ & 26 \\
\hline
\end{tabular}

Dalam penelitian ini, digunakan kuesioner dalam mengumpulkan data. Indikator-indikator pada Tabel 2 digunakan untuk menyusun instrumen kuesioner. Populasi karyawan sejumlah 150 dan ditarik secara simple random sampling menjadi sampel penelitian ini menggunakan rumus Slovin sebanyak 60 orang. Penelitian ini berlangsung pada tahun 2019 . 


\section{HASIL DAN PEMBAHASAN}

\section{Hasil}

\section{Uji Normalitas}

Uji normalitas merupakan uji untuk mengetahui apakah residual model regresi yang diteliti berdistribusi normal atau tidak. Uji normalitas residual dengan metode grafik adalah mengamati penyebaran data pada sumber diagonal di grafik Normal P-P Plot of regression standardized residual. Jika titik- titik menyebar sekitar garis dan mengikuti garis diagonal maka nilai residual tersebut telah normal.

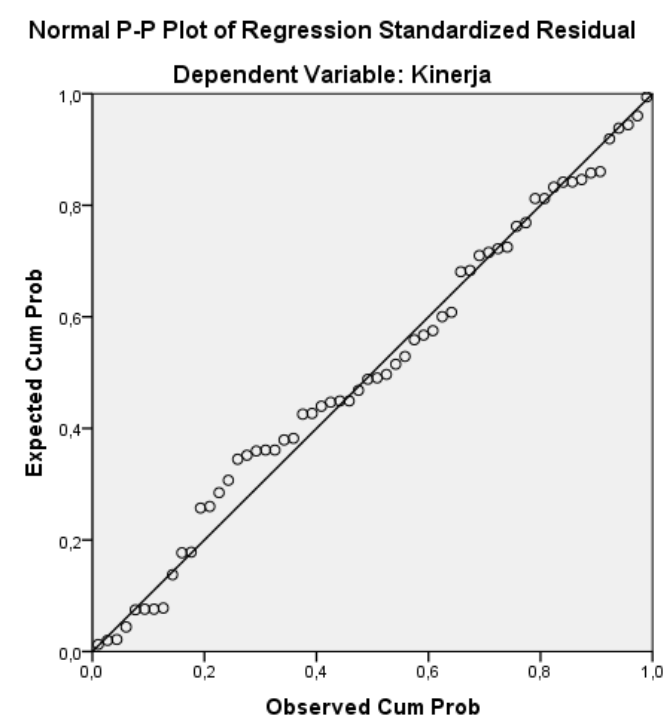

Gambar 2 Hasil Uji Normalitas P-Plot Kompensasi terhadap Kinerja Karyawan

Dari gambar 2 di atas dapat diketahui bahwa titik-titik menyebar sekitar garis dan mengikuti garis diagonal maka nilai residual tersebut terdistribusi normal.

\section{Uji Koefisien Korelasi}

Berikut hasil uji koefisien korelasi untuk mengatahui kuat lemahnya hubungan antar variabel.

Tabel 3 Uji Koefisien Korelasi

\begin{tabular}{|c|c|c|c|c|c|c|c|c|c|}
\hline \multicolumn{10}{|c|}{ Model Summary } \\
\hline \multirow[b]{2}{*}{ Model } & \multirow[b]{2}{*}{$\mathrm{R}$} & \multirow[b]{2}{*}{$\begin{array}{c}\mathrm{R} \\
\text { Square }\end{array}$} & \multirow[b]{2}{*}{$\begin{array}{l}\text { Adjusted } \\
\text { R Square }\end{array}$} & \multirow{2}{*}{$\begin{array}{c}\text { Std. } \\
\text { Error of } \\
\text { the } \\
\text { Estimate }\end{array}$} & \multicolumn{5}{|c|}{ Change Statistics } \\
\hline & & & & & $\begin{array}{l}\text { R Square } \\
\text { Change }\end{array}$ & $\begin{array}{c}\mathrm{F} \\
\text { Change }\end{array}$ & df1 & df2 & $\begin{array}{c}\text { Sig. F } \\
\text { Change }\end{array}$ \\
\hline 1 &, $452^{\mathrm{a}}$ & 0,204 & 0,176 & 4,665 & 0,204 & 7,309 & 2 & 57 & 0,001 \\
\hline
\end{tabular}

a. Predictors: (Constant), Kompensasi

Sumber : Hasil Penelitian Diolah Menggunakan SPSS 24

Berdasarkan Tabel 3 diketahui $\mathrm{R}=0,452$ yang artinya ada hubungan sedang antara variabel independent yaitu kompensasi terhadap variabel dependent yaitu kinerja karyawan.

\section{Uji Analisis Koefisien Determinasi}

Koefisien determinasi digunakan untuk mengetahui persentase kontribusi terhadap variabel independent bersama-sama terhadap variabel dependent, dengan menguji nilai $r^{2}$. Adapun hasil analisis koefisien determinasi dalam penelitian ini terlihat pada Tabel 4 
Tabel 4 Hasil Uji Analisis Koefisien Determinasi

\begin{tabular}{|c|c|c|c|c|c|c|c|c|c|}
\hline \multicolumn{10}{|c|}{ Model Summary } \\
\hline & & & & & & Chang & tatistic & & \\
\hline Model & $\mathrm{R}$ & $\begin{array}{c}\mathrm{R} \\
\text { Square }\end{array}$ & $\begin{array}{l}\text { Adjusted } \\
\text { R Square }\end{array}$ & $\begin{array}{l}\text { of the } \\
\text { Estimate }\end{array}$ & $\begin{array}{l}\text { R Square } \\
\text { Change }\end{array}$ & $\begin{array}{c}\mathrm{F} \\
\text { Change }\end{array}$ & df1 & df2 & $\begin{array}{l}\text { Sig. F } \\
\text { Change }\end{array}$ \\
\hline 1 &, $452^{\mathrm{a}}$ & 0,204 & 0,176 & 4,665 & 0,204 & 7,309 & 2 & 57 & 0,001 \\
\hline
\end{tabular}

a. Predictors: (Constant), Kompensasi

Sumber : Hasil Penelitian Diolah Menggunakan SPSS 24

Berdasarkan Tabel 4, nilai R square sebesar 0,204 berarti bahwa kompensasi terhadap kinerja melalui berpengaruh sebear $20,4 \%$ sisanya $79,6 \%$ dipengaruhi oleh variabel lain yang tidak diamati pada penelitian ini.

\section{Uji Hipotesis $\mathbf{t}$}

Uji hipotesi t dalam penelitian ini hasilnya disajikan pada Tabel 5 berikut

Tabel 5 Hasil uji T Kompensasi (X) terhadap KinerjaKaryawan (Y)

\begin{tabular}{|c|c|c|c|c|c|c|}
\hline \multicolumn{7}{|c|}{ Coefficients ${ }^{a}$} \\
\hline \multirow{2}{*}{\multicolumn{2}{|c|}{ Model }} & \multicolumn{2}{|c|}{$\begin{array}{l}\text { Unstandardized } \\
\text { Coefficients }\end{array}$} & \multirow{2}{*}{$\begin{array}{c}\text { Standardized } \\
\text { Coefficients } \\
\text { Beta }\end{array}$} & \multirow[b]{2}{*}{$\mathrm{T}$} & \multirow[t]{2}{*}{ Sig. } \\
\hline & & $\mathrm{B}$ & $\begin{array}{l}\text { Std. } \\
\text { Error }\end{array}$ & & & \\
\hline \multirow[t]{2}{*}{1} & (Constant) & 32,322 & 3,196 & & 10,114 & 0,000 \\
\hline & Kompensasi & 0,308 & 0,117 & 0,326 & 2,627 & 0,011 \\
\hline
\end{tabular}

a. Dependent Variable: Kinerja

Sumber : Hasil Penelitian Diolah Menggunakan SPSS 24

Sesuai dengan Tabel 5 di atas yaitu hasil uji hipotesis menunjukkan bahwa nilai signifikan pengaruh

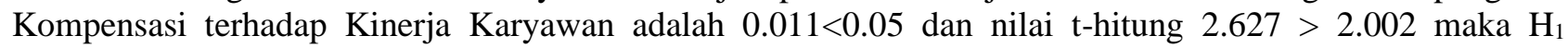
diterima dan $\mathrm{H}_{0}$ ditolak. Artinya Kompensasi berpengaruh dan signifikan terhadap Kinerja Karyawan pada PT. Mora Telematika Indonesia.

\section{Uji Regresi Linier Sederhana}

Dari Tabel 5 dapat disusun persamaan regresi linier $\mathbf{Y}=\mathbf{3 2 , 3 2 2}+\mathbf{0 , 3 0 8} \mathbf{X}$. Dari persamaan ini dapat diinterpretasikan bahwa hubungan variabel X (Kompensasi) terhadap variabel Y (Kinerja Karyawan) positif atau searah. Hasil tersebut menunjukkan bahwa setiap terjadi peningkatan Kompensasi sebesar satu satuan maka akan diikuti oleh peningkatan Kinerja Karyawan sebesar 32,222 satuan atau sebaliknya apabila terjadi penurunan Kompensasi sebesar satu satuan maka akan diikuti oleh penurunan Kinerja Karyawan sebesar 32,222 satuan.

\section{Pembahasan}

Hasil penelitian menunjukkan nilai t-hitung lebih besar dari t-tabel, maka hipotesis pertama $\left(\mathrm{H}_{1}\right)$ diterima $\left(\mathrm{H}_{0}\right)$ ditolak. Hipotesis pertama $\left(\mathrm{H}_{1}\right)$ menyatakan kompensasi berpengaruh positif dan signifikan terhadap kinerja karyawan. Artinya, kompensasi berpengaruh secara langsung terhadap kinerja karyawan pada PT Mora Telematika Indonesia Jakarta. Hasil penelitian ini sesuai dengan penelitian sebelumnya yaitu kompensasi berpengaruh dan signifikan terhadap kinerja karyawan (Dito \& Lataruva, n.d.; Leonardo \& Andreani, 2015; Poluakan et al., 2019). Bila kompensasi yang diberikan sepadan dengan kerja karyawan, maka karyawan akan lebih bersikap profesional dan berupaya mencapai kinerja yang lebih baik, yang tentunya akan memajukan jalannya usaha perusahaan. (Nurjaman, 2014).

Pengujian koefisien korelasi pada penelitian ini adalah 0,452. Hasil ini menunjukkan besarnya atau kekuatan variabel independen terhadap variabel dependen secara bersama. Hasil tersebut menunjukkan 
kategori sedang. Pada Koefisien Determinasi $\left(\mathrm{R}^{2}\right)$ yakni dengan nilai sebesar 0,204 atau $20.4 \%$, berarti besarnya kontribusi variabel independen terhadap variabel dependen adalah 20,4\%. Sementara sisanya 79,6\% merupakan konstribusi dari variabel-variabel lain yang tidak diteliti dalam penelitian ini.

\section{SIMPULAN DAN SARAN}

\section{Simpulan}

Berdasarkan hasil penelitian dan pembahasan dapat ditarik kesimpulan sesuai dengan tujuan penelitian:

1. Pengaruh variabel Kompensasi terhadap variabel Kinerja Karyawan seperti yang ditunjukkan oleh persamaan regresi linier $\mathrm{Y}=32,322+0,308 \mathrm{X}$ adalah berpengaruh positif atau searah. Hasil ini diperkuat dengan Uji Hipotesis t yang membuktikan bahwa variabel Kompensasi berpengaruh signifikan dan positif terhadap Kinerja Karyawan PT. Mora Telematika Indonesia, dengan nilai t-hitung sebesar 2.627 lebih dari t-tabel 2.002 serta nilai sig. sebesar 0,011 lebih besar dari 0.05.

2. Besarnya pengaruh variabel Kompensasi terhadap Kinerja Karyawan ditunjukkan oleh hasil koefisien korelasi (r) pada penelitian ini sebesar 0,452, yang menunjukkan besarnya atau kekuatan variabel Kompensasi terhadap variabel Kinerja Karyawan termasuk kategori sedang. Sedangkan nilai koefisien determinasi $\left(\mathrm{r}^{2}\right)$ yakni dengan nilai sebesar 0,204 atau 20.4\%, yang berarti besarnya kontribusi variabel Kompensasi terhadap variabel Kinerja Karyawan adalah 20,4\%. Sementara sisanya 79,6\% merupakan konstribusi dari variabel-variabel lain yang tidak diteliti dalam penelitian ini.

\section{Saran}

Disarankan melakukan penelitian lebih lanjut, terkait variabel independen lain, selain variabel penelitian ini (Kompensasi). Selain itu, disarankan untuk menggali kembali variabel yang diteliti, sehingga akan memberikan masukan bagi pihak-pihak yang berkepentingan.

\section{DAFTAR PUSTAKA}

[1]. Armstrong, M., \& Baron, A. (2005). Managing Performance: Performance Management in Action. CIPD Publishing.

[2]. Dito, A. H., \& Lataruva, E. (n.d.). Pengaruh Kompensasi Terhadap Kinerja Karyawan Pt. Slamet Langgeng Purbalingga Dengan Motivasi Kerja Sebagai Variabel Intervening. 2010. http://eprints.undip.ac.id/23253/

[3]. Handoko, T. H. (2014). Manajemen Personalia dan Sumber Daya Manusia (2nd ed.). BPFE.

[4]. Leonardo, E., \& Andreani, F. (2015). Pengaruh Pemberian Kompensasi Terhadap Kinerja Karyawan Pada PT . Kopanitia. Agora, 3(2), 3-6.

[5]. Mangkunegara, A. A. P. (2007). Manajemen Sumber Daya Manusia Perusahaan. PT Remaja Rosdakarya.

[6]. Nawawi. (2011). Manajemen Sumber Daya Manusia: Untuk Bisnis yang Kompetitif. Gajah Mada University Press.

[7]. Nurcahyani, N. M., \& Adnyani, I. G. A. D. (2016). Pengaruh Kompensasi Dan Motivasi Terhadap Kinerja Karyawan Dengan Kepuasan Kerja Sebagai Variabel Intervening. Manajemen, 5(1). https://ojs.unud.ac.id/index.php/Manajemen/article/view/16159

[8]. Nurjaman, K. (2014). Manajemen Personalia. CV Pustaka Setia.

[9]. Poluakan, A. K., Runtuwene, R. F., \& Sambul, S. A. P. (2019). Pengaruh Kompensasi Terhadap Kinerja Pegawai. Jurnal Administrasi Bisnis, 9(2), 70-77.

[10]. Shalahuddin, A., \& Marpaung, B. P. (2014). Pengaruh Kompensasi Dan Budaya Organisasi Terhadap Kinerja Pegawai Dengan Motivasi Kerja Sebagai Variabel Perantara. Manajemen Teori Dan Terapan, 7(1). https://doi.org/http://dx.doi.org/10.20473/jmtt.v7i1.2685

[11]. Vikaliana, R., \& Irwansyah. (2019). Pengolahan Data dengan SPSS. CV AA RIZKY. 